CNS Spectrums, (2019), 24 354-370. (C) Cambridge University Press 2018. This is an Open Access article, distributed under the terms of the Creative Commons Attribution-NonCommercial-NoDerivatives licence (http://creativecommons.org/licenses/by-nc-nd/4.0/), which permits non-commercial re-use, distribution, and reproduction in any medium, provided the original work is unaltered and is properly cited. The written permission of Cambridge University Press must be obtained for commercial re-use or in order to create a derivative work.

\title{
Practical considerations for managing breakthrough psychosis and symptomatic worsening in patients with schizophrenia on long-acting injectable antipsychotics
}

\author{
Christoph U. Correll (iD, ${ }^{1,2}$ Jennifer Kern Sliwa iD, ${ }^{3 *}$ Dean M. Najarian iD, ${ }^{3}$ and \\ Stephen R. Saklad ${ }^{4}$
}

\footnotetext{
${ }^{1}$ Department of Psychiatry and Molecular Medicine, Hofstra Northwell School of Medicine, Hempstead, New York

${ }^{2}$ Division of Psychiatry Research, Zucker Hillside Hospital, Northwell Health, Glen Oaks, New York

${ }^{3}$ Janssen Scientific Affairs LLC, Titusville, New Jersey

${ }^{4}$ College of Pharmacy, Pharmacotherapy Division, University of Texas at Austin, San Antonio, Texas
}

With more long-acting injectable (LAI) antipsychotics available for treating schizophrenia, each with variable durations of action (2 weeks to 3 months), it is important to have clear management strategies for patients developing breakthrough psychotic symptoms or experiencing symptomatic worsening on LAIs. However, no treatment guidelines or clinical practice pathways exist; health-care providers must rely on their own clinical judgment to manage these patients. This article provides practical recommendations-based on a framework of clinical, pharmacokinetic, and dosing considerations-to guide clinicians' decisions regarding management of breakthrough psychotic symptoms. Management options include ruling out/addressing medical illness or substance abuse/misuse as a contributing factor, addressing stressors, optimizing nonpharmacologic treatments, treating medical/psychiatric comorbidities, ensuring proper LAI administration technique, addressing missed LAI doses or lack of steady-state attainment, and increasing LAI dose directly or indirectly by shortening the injection interval (off-label). If these strategies do not work sufficiently with frequent monitoring, the LAI could be supplemented with a low dose of the corresponding oral formulation for fast symptom control (off-label). However, caution should be exercised with this strategy, because data on the safety of concomitant use of LAI and oral antipsychotics (OAPs) are limited, especially over extended periods. If symptoms abate, therapy optimization could be continued and slow discontinuation of the OAP could be considered. For persistent/worsening symptoms, the OAP should be increased to optimum effective dose while intensifying the initial steps used before it was added. If this fails, switching the OAP or LAI could be considered. We believe that these strategies will help clinicians manage breakthrough psychotic symptoms during LAI treatment and improve overall outcomes among those who can benefit from LAIs.

Received 20 December 2017; Accepted 23 May 2018; First published online 27 December 2018

Key words: Antipsychotic, breakthrough symptoms, long-acting injectable, management strategy, schizophrenia, symptomatic worsening.

\section{Introduction}

The use of long-acting injectable (LAI) antipsychotics for the treatment of patients with schizophrenia decreased significantly after oral formulations of second-generation

* Address correspondence to: Jennifer Kern Sliwa, Neuroscience Medical Information, Janssen Scientific Affairs LLC, 1125 TrentonHarbourton Road, Titusville, NJ 08560.

(Email: jkernsli@its.jnj.com) antipsychotics were introduced; however, the use of LAIs has increased slowly in recent years since the introduction of second-generation LAI antipsychotics. ${ }^{1,2}$ Earlier data estimated that LAI antipsychotics were prescribed to between one-quarter and one-third of patients with schizophrenia in the United States, Australia, and Europe $^{3,4}$; more recent data (2016) from the United States indicate that $11 \%$ of patients are prescribed LAI antipsychotics (data on file, Janssen). 
LAI antipsychotics offer advantages over oral formulations, ${ }^{1}$ because they provide assured adherence for the duration of the injection interval and beyond; this is particularly important for patients who have a history of poor adherence, lack of insight into their illness, or cognitive deficits that interfere with scheduled medication intake. ${ }^{1}$ Because patients receiving LAI antipsychotics do not have to remember to take medication daily, there are fewer opportunities for missed doses. ${ }^{1}$ With LAI antipsychotics, health-care providers (HCPs) are assured of continuous antipsychotic coverage during the dosing interval. In cases of patients failing to take their medication, there is a longer window for intervention, as the decrease of blood concentrations of antipsychotics is much more gradual after discontinuation of LAI antipsychotics than after discontinuation of oral antipsychotics (OAPs). ${ }^{1,5,6}$ Patients also benefit from consistent bioavailability and potentially fewer peak concentration-related adverse events (AEs) observed with OAPs. ${ }^{7}$ Furthermore, clinicians are immediately aware when medication nonadherence begins (i.e., patients do not return for their scheduled injections). ${ }^{1}$ Importantly, there is evidence that LAI antipsychotics reduce the incidence of relapse compared with oral formulations. ${ }^{1,2,7}$ This in turn can decrease the frequency and duration of hospital stays associated with relapse, thereby reducing the overall burden on the patient and their caregivers, and on the health-care system. ${ }^{2,8,9}$

Given that there are several first-generation LAI antipsychotics still on the market as well as an influx of newly available second-generation LAI antipsychotics (Table 1), it can be challenging to delineate which LAI antipsychotic is most appropriate for a particular patient. However, there are several practical considerations that should be considered when selecting a specific LAI. Because each LAI has unique attributes, selection should be tailored to match the unique needs of the individual. First, the HCP should consider the reason for using an LAI antipsychotic (e.g., patient preference, nonadherence, court order). The patient and the HCP should then discuss factors important to the patient, such as the expected or already experienced efficacy and $\mathrm{AE}$ pattern of the oral formulation of the same antipsychotic, the frequency of administration, whether an oral supplement is required upon initiation, and the financial cost or coverage of the treatment. ${ }^{10}$ One potential disadvantage of LAI antipsychotics is the potential for delayed resolution of a distressing or severe side effect. ${ }^{1}$ HCP-specific practical considerations might include how each LAI is supplied, such as in prefilled syringes or in a form that requires reconstitution, and specific storage requirements (e.g., whether refrigeration is necessary). Limited or incomplete information on first-generation LAIs, such as the lack of drugmetabolism or drug-interaction data (these drugs were approved before the implementation of such US Food and Drug Administration requirements), may either preclude them as a viable choice for HCPs or make them difficult to use. Patient-specific practical considerations include access to care, needle size, or injection site location. ${ }^{10}$ Thorough consideration of patient- and HCPspecific preferences will help guide selection of the appropriate LAI antipsychotic and potentially improve adherence and effectiveness among patients.

Despite the many advantages that LAI antipsychotics offer over oral formulations, ${ }^{1}$ patients may experience psychotic breakthrough symptoms or symptomatic worsening during treatment, such as psychosis-related social withdrawal, anxiety, or depression; parkinsonian side effect-related secondary negative symptoms; or akathisia manifesting as agitation. Unfortunately, there is a paucity of data regarding management strategies in response to patients experiencing breakthrough symptoms, with only three articles identified during a recent literature search. ${ }^{11-13}$ There are currently no algorithms, treatment guidelines, or clinical pathways to guide the management of LAI antipsychotic-treated patients who have breakthrough symptoms or who become acutely ill. Moreover, the only available guidelines for the therapeutic targets of LAI antipsychotics, produced by Arbeitsgemeinschaft für Neuropsychopharmakologie und Pharmakopsychiatrie (AGNP), are based on data from oral compounds. ${ }^{14,15}$ Therefore, HCPs must currently rely on their own clinical judgment to manage patients with breakthrough symptoms or symptomatic worsening. Herein, we provide practical solutions based on a framework of clinical, pharmacokinetic (PK), and dosing considerations to help HCPs make well-informed decisions regarding management strategies for patients presenting with breakthrough psychotic symptoms or symptomatic worsening while being treated with LAI antipsychotics.

\section{General Factors That Contribute to Breakthrough Psychosis and/or Symptom Worsening}

Breakthrough psychosis and/or symptom worsening may occur for a variety of reasons, including psychotic relapse, concurrent medical illness, substance abuse or misuse, other psychiatric comorbidity, psychosocial stressors, suboptimal drug administration, incorrect dosage, ineffective medication, use of other drugs leading to pharmacodynamic (PD) or PK interactions, poor adherence, and AEs leading to refusal or discontinuation of treatment. ${ }^{1,2,16}$ Low plasma therapeutic levels may also contribute to breakthrough psychosis. Therapeutic plasma reference ranges are now available in the new AGNP guidelines, ${ }^{15}$ and while these are preliminary, together with therapeutic dose monitoring they may be of some use toward medication and dosing decision making, as exemplified in Table $2 .^{17}$ Idiopathic 


\begin{tabular}{|c|c|c|c|c|c|c|c|c|c|c|c|}
\hline & Base & Dose interval & $\begin{array}{l}\text { Dosage forms/ } \\
\text { strengths }^{\mathrm{a}}\end{array}$ & Shaking information & Storage information & Reconstitution & $\begin{array}{c}\text { Oral } \\
\text { supplementation }\end{array}$ & Time to peak ${ }^{\mathrm{b}}$. & Steady state ${ }^{\mathrm{e}}$ & $\begin{array}{l}\text { Postinjection } \\
\text { observation }\end{array}$ & $\begin{array}{l}\text { Therapeutic reference } \\
\text { blood concentrations }\end{array}$ \\
\hline $\begin{array}{l}\text { First generation } \\
\text { Flupenthixol decanoate }\end{array}$ & $\begin{array}{l}\text { Medium-chain } \\
\text { triglycerides }\end{array}$ & $2-3$ weeks & $\begin{array}{l}20 \text { and } 100 \mathrm{mg} / \mathrm{mL} \\
\text { ampules }\end{array}$ & - & $\begin{array}{l}\text { Store between } 15^{\circ} \text { and } 25^{\circ} \mathrm{C} \text {. } \\
\text { Protect from light. }\end{array}$ & - & 1 week & 4-7 days & $\sim 3$ months & No & $0.5-5 \mathrm{ng} / \mathrm{mL}$ \\
\hline Fluphenazine decanoate & Oil & Varies & $\begin{array}{l}25 \text { and } 100 \mathrm{mg} / \mathrm{mL} \\
\text { ampules/vials/ } \\
\text { syringes }\end{array}$ & - & $\begin{array}{l}\text { Store at } 20^{\circ} \text { to } 25^{\circ} \mathrm{C}\left(68^{\circ} \mathrm{F}-\right. \\
\left.77^{\circ}\right) \text {. Protect from light. }\end{array}$ & - & No & 24 hours & $2-3$ months & No & $1-10 \mathrm{ng} / \mathrm{mL}$ \\
\hline Haloperidol decanoate & Oil & 4 weeks & $\begin{array}{l}50 \text { and } 100 \mathrm{mg} / \mathrm{mL} \\
(70.52 \mathrm{and} \\
141.04 \mathrm{mg} / \mathrm{mL}) \\
\text { ampules }\end{array}$ & - & $\begin{array}{l}\text { Store at controlled room } \\
\text { temperature }\left(15^{\circ} \mathrm{C}-30^{\circ} \mathrm{C} \text {, }\right. \\
59^{\circ}-86^{\circ} \text { F). Do not } \\
\text { refrigerate or freeze. } \\
\text { Protect from light. }\end{array}$ & - & No & $6-7$ days & $\begin{array}{l}\text { After third or } \\
\text { fourth dose }\end{array}$ & No & $1-10 \mathrm{ng} / \mathrm{mL}$ \\
\hline $\begin{array}{c}\text { Zuclopenthixol } \\
\text { decanoate }\end{array}$ & $\begin{array}{l}\text { Medium-chain } \\
\text { triglycerides }\end{array}$ & $2-4$ weeks & $200 \mathrm{mg} / \mathrm{mL}$ & 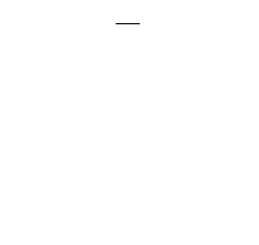 & $\begin{array}{l}\text { Store between } 15^{\circ} \text { and } 25^{\circ} \mathrm{C} \text {. } \\
\text { Protect from light. } \\
\text { Discard unused portion. }\end{array}$ & 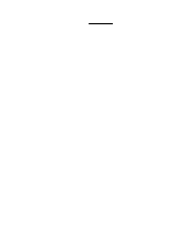 & $\begin{array}{l}\text { May be required } \\
\text { in diminishing } \\
\text { dosage } \\
\text { following } \\
\text { initiation of } \\
\text { depot } \\
\text { treatment }\end{array}$ & 3-7 days & - & № & $4-50 \mathrm{ng} / \mathrm{mL}$ \\
\hline $\begin{array}{l}\text { Second generation } \\
\text { Aripiprazole lauroxil } \\
\text { (Aristada }{ }^{\circledR} \text { ) }\end{array}$ & Water & $\begin{array}{l}\text { Monthly (or } \\
\text { every } \\
6 \text { weeks: } \\
882 \mathrm{mg} \text { or } \\
\text { every } \\
2 \text { months: } \\
1064 \mathrm{mg} \text { ) }\end{array}$ & $\begin{array}{l}\text { 441, } 662,882 \text {, and } \\
1064 \mathrm{mg} \\
(300,450,600 \text {, and } \\
724 \mathrm{mg}) \text { prefilled } \\
\text { syringes }\end{array}$ & $\begin{array}{l}\text { Prefilled syringe: Tap the } \\
\text { syringe at least } 10 \text { times } \\
\text { to dislodge any material } \\
\text { that may have settled. } \\
\text { Shake the syringe } \\
\text { vigoroussly for a } \\
\text { minimum of } 30 \text { seconds } \\
\text { to ensure a uniform } \\
\text { suspension. Administer } \\
\text { rapidlly, continuously, } \\
\text { and without hesitation. }\end{array}$ & $\begin{array}{l}\text { Store at room temperature } \\
\left(20^{\circ} \mathrm{C}-25^{\circ} \mathrm{C}, 68^{\circ}-77^{\circ} \mathrm{F}\right) \\
\text { with excursions permitted } \\
\text { between } 15^{\circ} \mathrm{C} \text { and } 30^{\circ} \mathrm{C} \\
\text { (between } 59^{\circ} \text { F and } 86^{\circ} \text { F) }\end{array}$ & $\begin{array}{l}\text { If the syringe is not } \\
\text { used within } \\
15 \text { minutes, } \\
\text { shake again for } \\
30 \text { seconds. }\end{array}$ & 3 weeks & $\begin{array}{l}\text { 44-50 days } \\
\text { after a } \\
\text { single } \\
441 \mathrm{mg} \\
\text { dose }\end{array}$ & 4 months & No & $\begin{array}{l}\text { 100-350 ng/mL } \\
\text { (aripiprazole) } \\
150-500 \mathrm{ng} / \mathrm{mL} \\
\text { (aripiprazole plus } \\
\text { dehyroaripiprazole) }\end{array}$ \\
\hline
\end{tabular}




\begin{tabular}{|c|c|c|c|c|c|c|c|c|c|c|c|}
\hline & Base & Dose interval & $\begin{array}{l}\text { Dosage forms/ } \\
\text { strengths }^{\mathrm{a}}\end{array}$ & Shaking information & Storage information & Reconstitution & $\begin{array}{c}\text { Oral } \\
\text { supplementation }\end{array}$ & Time to peak & Steady state ${ }^{\mathrm{e}}$ & $\begin{array}{l}\text { Postinjection } \\
\text { observation }\end{array}$ & $\begin{array}{l}\text { Therapeutic reference } \\
\text { blood concentrations }{ }^{c}\end{array}$ \\
\hline $\begin{array}{l}\text { Aripiprazole } \\
\text { monohydrate (Abilify } \\
\text { Maintena }{ }^{\circledR} \text { ) }\end{array}$ & Water & Monthly & $\begin{array}{l}\text { 300, } 400 \mathrm{mg} \text { vial kits } \\
\text { and dual-chamber } \\
\text { syringe }\end{array}$ & $\begin{array}{l}\text { Prefilled dual-chamber } \\
\text { syringe: Rotate plunger } \\
\text { until rod stops rotating } \\
\text { to release diluent. } \\
\text { Vertically shake the } \\
\text { syringe vigorously for } \\
20 \text { seconds until drug is } \\
\text { uniformly milky-white, } \\
\text { uniform, and } \\
\text { homogenous. Twist and } \\
\text { pull off over-cap and } \\
\text { tip-cap before selecting } \\
\text { the appropriate needle } \\
\text { (according to body type } \\
\text { and injection site). } \\
\text { Vial kits: Inject diluent } \\
\text { into vial and shake the } \\
\text { vial vigorously for } \\
30 \text { seconds until the } \\
\text { reconstituted } \\
\text { suspension appears } \\
\text { uniform. }\end{array}$ & $\begin{array}{l}\text { Prefilled dual chamber } \\
\text { syringe: Store below } 30^{\circ} \mathrm{C} \\
\left(86^{\circ} \mathrm{F}\right) \text {. } \\
\text { Vial: Store at } 25^{\circ} \mathrm{C}\left(77^{\circ} \mathrm{F}\right) \text {, } \\
\text { excursions permitted } \\
\text { between } 15^{\circ} \mathrm{C} \text { and } 30^{\circ} \mathrm{C} \\
\left(59^{\circ} \mathrm{F}-86^{\circ} \mathrm{F}\right)\end{array}$ & $\begin{array}{l}\text { If the injection is } \\
\text { not performed } \\
\text { immediately } \\
\text { after } \\
\text { reconstitution, } \\
\text { keep the vial at } \\
\text { room } \\
\text { temperature } \\
\text { and shake the } \\
\text { vial vigorously } \\
\text { for at least } \\
60 \text { seconds to } \\
\text { resuspend } \\
\text { before injecting. } \\
\text { Do not store the } \\
\text { reconstituted } \\
\text { suspension in a } \\
\text { syringe. }\end{array}$ & 2 weeks & $\begin{array}{l}\text { Gluteal: 5- } \\
7 \text { days; } \\
\text { deltoid: } \\
4 \text { days } \\
\text { (following } \\
\text { multiple } \\
\text { intramus- } \\
\text { cular } \\
\text { doses) }\end{array}$ & $\begin{array}{l}\text { 400: } 4- \\
8 \text { months } \\
300: 3- \\
4 \text { months }\end{array}$ & No & $\begin{array}{l}\text { 100-350 ng/mL } \\
\text { (aripiprazole) } \\
150-500 \mathrm{ng} / \mathrm{mL} \\
\text { (aripiprazole plus } \\
\text { dehyroaripiprazole) }\end{array}$ \\
\hline $\begin{array}{l}\text { Olanzapine pamoate } \\
\left.\quad \text { (Zyprexa Relprevv }^{\circledR}\right)\end{array}$ & Water & 2 or 4 weeks & $\begin{array}{l}\text { 210, 300, } 405 \mathrm{mg}(483, \\
690 \text {, and } 931 \mathrm{mg}) \\
\text { vial kits }\end{array}$ & $\begin{array}{l}\text { Shake vigorously until } \\
\text { suspension is consistent } \\
\text { (yellow and opaque). } \\
\text { Suspension is stable up } \\
\text { to } 24 \text { hours after } \\
\text { reconstitution, but } \\
\text { should be resuspended } \\
\text { by shaking upon use. }\end{array}$ & $\begin{array}{l}\text { Store at room temperature not } \\
\text { to exceed } 30^{\circ} \mathrm{C}\left(86^{\circ} \mathrm{F}\right) \text {. } \\
\text { When the drug is } \\
\text { suspended in the solution } \\
\text { for Zyprexa Relprevv }{ }^{\circledR} \text {, it } \\
\text { may be held at room } \\
\text { temperature for } 24 \text { hours. }\end{array}$ & $\begin{array}{l}\text { Tap the vial firmly } \\
\text { and repeatedly } \\
\text { on the surface } \\
\text { until no powder } \\
\text { is visible. If } \\
\text { foam forms, let } \\
\text { foam dissipate } \\
\text { first. Product } \\
\text { must be } \\
\text { reconstituted in } \\
\text { the diluent } \\
\text { provided and } \\
\text { immediately }\end{array}$ & No & 2-4 days & 3 months & Yes: $3 \mathrm{~h}$ & $20-80 \mathrm{ng} / \mathrm{mL}$ \\
\hline
\end{tabular}




\begin{tabular}{|c|c|c|c|c|c|c|c|c|c|c|c|}
\hline $\begin{array}{l}\text { PP1M (Invega } \\
\text { Sustenna }{ }^{\circledR} \text { ) }\end{array}$ & Water & Monthly & $\begin{array}{l}39,78,117,156, \\
234 \mathrm{mg}(25,50,75, \\
100,150 \mathrm{mg}) \\
\text { prefilled syringes }\end{array}$ & $\begin{array}{l}\text { Shake syringe vigorously for } \\
\geq 10 \text { seconds }\end{array}$ & $\begin{array}{l}\text { Store at room temperature } \\
\left(25^{\circ} \mathrm{C}, 77^{\circ} \mathrm{F}\right) \text {; excursions } \\
\text { between } 15^{\circ} \mathrm{C} \text { and } 30^{\circ} \mathrm{C} \\
\text { (between } 59^{\circ} \mathrm{F} \text { and } 86^{\circ} \mathrm{F} \text { ) } \\
\text { are permitted. }\end{array}$ & Not applicable & No & 13 days & $7-11$ months & No & $\begin{array}{l}20-60 \mathrm{ng} / \mathrm{mL} \\
\quad(9- \\
\text { hydroxyrisperidone) }\end{array}$ \\
\hline PP3M (Invega Trinza $\left.{ }^{\circledR}\right)$ & Water & Every 3 months & $\begin{array}{l}273,410,546,819 \mathrm{mg} \\
\text { (175, 263, } 350, \\
525 \mathrm{mg}) \text { prefilled } \\
\text { syringes } \\
\text { Note: There is not an } \\
\text { equivalent 3-month } \\
\text { dose of } 39 \mathrm{mg} \text { of } \\
\text { Invega Sustenna }\end{array}$ & $\begin{array}{l}\text { Shake syringe vigorously } \\
\text { with a loose wrist for } \\
\geq 15 \text { seconds with } \\
\text { syringe tip up and } \\
\text { administer within } \\
5 \text { minutes. }\end{array}$ & $\begin{array}{l}\text { Store at room temperature } \\
20^{\circ} \mathrm{C} \text { to } 25^{\circ} \mathrm{C}\left(68^{\circ} \mathrm{F}-77^{\circ}\right. \\
\mathrm{F}) \text {; excursions between } \\
15^{\circ} \mathrm{C} \text { and } 30^{\circ} \mathrm{C}\left(59^{\circ} \mathrm{F} \text { and }\right. \\
\left.86^{\circ} \mathrm{F}\right) \text { are permitted. }\end{array}$ & Not applicable & No & $30-33$ days & $\begin{array}{l}\text { Continues } \\
\text { steady state } \\
\text { at } \\
\text { equivalent } \\
\text { doses }\end{array}$ & No & $\begin{array}{l}20-60 \mathrm{ng} / \mathrm{mL} \\
\quad(9- \\
\text { hydroxyrisperidone) }\end{array}$ \\
\hline $\begin{array}{l}\text { Risperidone LAI } \\
\left.\quad \text { (Risperdal Consta }{ }^{\circledR}\right)\end{array}$ & Water & 2 weeks & $\begin{array}{l}12.5,25,37.5,50 \mathrm{mg} \\
\quad \text { vial kits }\end{array}$ & $\begin{array}{l}\text { Shake the vial with } \\
\text { attached syringe } \\
\text { vigorously for at least } 10 \\
\text { seconds before } \\
\text { injection. }\end{array}$ & $\begin{array}{l}\text { The entire dose pack should } \\
\text { be stored in the } \\
\text { refrigerator }\left(2^{\circ}-8^{\circ} \mathrm{C} \text {, }\right. \\
\left.36^{\circ}-46^{\circ} \mathrm{F}\right) \text { and protected } \\
\text { from light. If refrigeration } \\
\text { is unavailable, Risperdal } \\
\text { Consta }{ }^{\circledR} \text { can be stored at } \\
\text { temperatures not } \\
\text { exceeding } 25^{\circ} \mathrm{C}\left(77^{\circ} \mathrm{F}\right) \text { for } \\
\text { no more than } 7 \text { days } \\
\text { before administration. Do } \\
\text { not expose unrefrigerated } \\
\text { product to temperatures } \\
\text { above } 25^{\circ} \mathrm{C}\left(77^{\circ} \mathrm{F}\right) \text {. }\end{array}$ & $\begin{array}{l}\text { Remove dose pack } \\
\text { from the } \\
\text { refrigerator. Let } \\
\text { it sit at room } \\
\text { temperature for } \\
\text { at least } \\
30 \text { minutes } \\
\text { before } \\
\text { reconstituting. } \\
\text { Product must be } \\
\text { reconstituted in } \\
\text { the diluent } \\
\text { provided and } \\
\text { immediately } \\
\text { before } \\
\text { administration. }\end{array}$ & 3 weeks & 4 weeks & $\begin{array}{l}\text { Steady-state } \\
\text { plasma } \\
\text { concentra- } \\
\text { tions are } \\
\text { reached } \\
\text { after } 4 \\
\text { injections } \\
\text { and are } \\
\text { maintained } \\
\text { for } 4 \text { to } \\
6 \text { weeks } \\
\text { after the } \\
\text { last } \\
\text { injection }\end{array}$ & No & $\begin{array}{l}\text { 20-60 ng/mL } \\
\text { (risperidone plus } \\
\text { 9-hydroxy- } \\
\text { risperidone) }\end{array}$ \\
\hline
\end{tabular}

Dash $(-)=$ not applicable; LAI = long-acting injectable; PP1M = paliperidone palmitate once monthly; PP3M = paliperidone palmitate once every 3 months.

${ }^{\text {a }}$ For products available in the United States, doses are based on U.S. approval; doses in parentheses represent milligram-equivalent doses.

${ }^{b}$ Steady-state data refer to an ideal, average patient who is a "normal" metabolizer. These therapeutics may have a longer half-life in patients who are poor metabolizers (based on genetics or concomitant use of metabolic enzyme inhibitors) or a shorter half-life in those who are rapid metabolizers (based on genetics or concomitant use of metabolic enzyme inducers).

${ }^{\mathrm{c}}$ Data on therapeutic reference plasma concentrations are preliminary.

${ }^{\mathrm{d}}$ Time to peak values were derived from patients who received oral supplementation before LAl administration.

${ }^{\mathrm{e}}$ Most PK data originate from studies by the pharmaceutical industry; studies conducted by academic investigators are limited. 


\begin{tabular}{|c|c|c|c|c|}
\hline \multirow[b]{2}{*}{ Efficacy } & \multirow[b]{2}{*}{ Adverse effects } & \multicolumn{3}{|c|}{ Serum concentration compared with reference range } \\
\hline & & Low & Reasonable & High \\
\hline \multirow[t]{2}{*}{ Good } & None or mild & Continue & Continue & Continue \\
\hline & Moderate or severe & $\Delta$ & $\downarrow$ & $\downarrow$ \\
\hline \multirow[t]{2}{*}{ Poor } & None or mild & $\uparrow$ & $\uparrow$ & $\Delta$ \\
\hline & Moderate or severe & $\Delta$ & $\Delta$ & $\Delta$ \\
\hline
\end{tabular}

$\Delta=$ change to different medication; $\uparrow=$ increase the dose; $\downarrow=$ decrease the dose

symptomatic worsening and exacerbation of the illness for unknown, disease-related reasons despite continued antipsychotic treatment can also occur. It is critical to understand that breakthrough symptoms are not always an indication of treatment failure. Therefore, as a first step, HCPs should identify all potential factors that could contribute to specific symptoms or symptom clusters and devise patient-specific mitigation strategies to optimize outcomes (Figure 1).

\section{Relevance of Pharmacokinetic and Pharmacodynamic Aspects of Long-acting Injectable Antipsychotics}

The PK and PD profiles of LAIs may contribute to patients experiencing psychotic breakthrough symptoms and should be considered when evaluating a patient. The slow, gradual dose titration inherent with the use of many LAIs $^{18,19}$ may mean that a patient will experience residual symptoms or require oral supplementation until the LAI dosage is optimized and the steady state of therapeutic blood concentration is achieved. ${ }^{10,18}$ Both aripiprazole lauroxil (Aristada ${ }^{\circledR}$ ) and risperidone LAI (Risperdal Consta ${ }^{\circledR}$ ) require 3 weeks of oral supplementation, whereas aripiprazole monohydrate (Abilify Maintena ${ }^{\circledR}$ ) requires 2 weeks. A shorter, 1-week course of oral supplementation is needed with flupenthixol decanoate (Fluanxol ${ }^{\circledR}$; Table 1). The proper administration of LAI antipsychotics is essential for establishing effective plasma concentrations. This includes sufficient shaking of atypical LAIs before injection (if required);

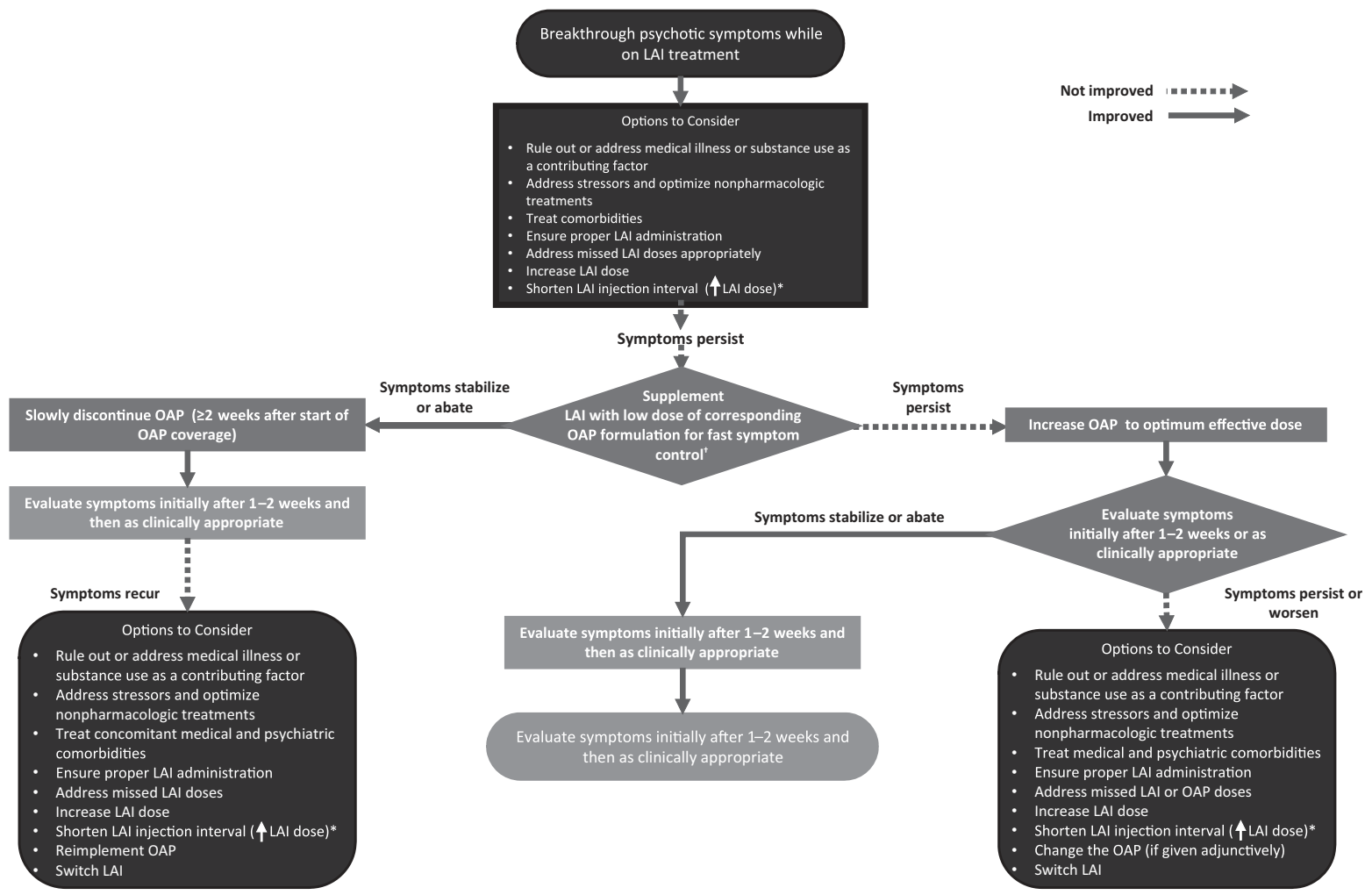

FIGURE 1. Management of breakthrough psychotic symptoms in a patient receiving long-acting injectable (LAI) antipsychotic in whom the LAl antipsychotic dose has been optimized. LAI = long-acting injectable; OAP = oral antipsychotic. *Off-label; based on PK modeling (no supporting clinical trial data available). ${ }^{17 \dagger}$ Caution should be exercised with this strategy, because data on the safety of concomitant use of LAl and oral antipsychotics are limited, especially over extended periods of time. 
Z-track injections for first-generation sesame oil preparations; choosing the appropriate needle size and administration site; injecting the LAI antipsychotic into the muscle, not fat tissue; and in some cases, administering the injection rapidly and without hesitation (because aripiprazole lauroxil is thixotropic, it may block the syringe if it is not injected rapidly; Table 1). ${ }^{10,20}$ If these steps are not taken during LAI administration, effective plasma concentrations may not be reached or sustained. In addition, missed LAI doses and their effect on blood concentrations must be accounted for and may require potentially restarting the initiation doses or administering booster injections (Table 3). Drug-drug interactions must also be taken into consideration as a potential cause of symptom breakthrough or psychotic symptom worsening. ${ }^{10}$ Carbamazepine, a potent inducer of several drug-elimination pathways, can decrease plasma concentrations of risperidone or aripiprazole LAI, whereas the selective serotonin-reuptake inhibitors fluoxetine and paroxetine can increase the plasma concentrations of risperidone or aripiprazole LAI. ${ }^{10,21,22}$ Furthermore, clozapine (serotonin dopamine-receptor antagonist) may impair clearance of risperidone, whereas the $\mathrm{H}_{2}$-receptor inhibitors cimetidine and ranitidine can increase its bioavailability. ${ }^{10}$

Carbamazepine is also known to increase the clearance rates of olanzapine, whereas fluvoxamine has been shown to increase the concentrations of olanzapine. ${ }^{10}$ Strong CYP3A4/P-glycoprotein inducers (e.g., carbamazepine, rifampin, St. John's wort) given concomitantly with LAI formulations of paliperidone palmitate may decrease the exposure to paliperidone. ${ }^{23,24}$ If administration of a strong CYP3A4/P-glycoprotein inducer during the dosing interval is necessary, it is recommended that the patient be managed with paliperidone extended-release tablets. ${ }^{23,24}$ Renal function is an important factor for paliperidone, such that LAI paliperidone palmitate (Invega Sustenna ${ }^{\circledR}$ and Invega Trinza $\left.{ }^{\circledR}\right)$ is not recommended for use in patients with moderate or severe renal impairment, and only lower doses should be administered in patients with mild impairment. ${ }^{24}$ Dosage adjustments are recommended in patients who are treated concomitantly with aripiprazole and strong CYP3A4/CYP2D6 inducers and for those who are poor CYP2D6 metabolizers. ${ }^{10}$ In poor CYP2D6 metabolizers, the dose of aripiprazole should be reduced. In patients who are CYP2D6 ultra-rapid metabolizers, it has been demonstrated that plasma levels of some LAIs (aripiprazole, haloperidol, risperidone, zuclopenthixol) are reduced ${ }^{25}$; however, the need to increase LAI dosing in these patients has yet to be established. In one small study of 85 patients taking risperidone, there was no indication that the subtherapeutic levels of the drug found in three CYP3D6 ultrarapid metabolizers affected either the efficacy or tolerability of the LAI in these patients. ${ }^{26}$ Modeling of the interaction between CYP2D6 inhibitors and oral aripiprazole suggests that dose alteration is not required for courses of CYP2D6 inhibitors lasting $\leq 2$ weeks. $^{20,22}$ Therefore, the dose of LAI should not be automatically adjusted if a patient is on a short course of enzyme inducer or inhibitor (Supplemental Table 1); rather, the patient should be monitored for adverse effects and the dose increased only after persistent problems arise. An overview of clinically relevant drug interactions for firstand second-generation LAIs is shown in Supplemental Table 2. A more detailed description of the PK/PD properties and interactions of LAIs is reviewed elsewhere. ${ }^{14,27-29}$

\section{Management of Symptomatic/Breakthrough IIIness: Practical Considerations}

\section{Clinical scenario: LAI antipsychotic-treated patient presenting with exacerbation of symptoms}

Patients receiving LAI antipsychotics who experience acute exacerbation of psychotic symptoms may present at a psychiatrist's office or the emergency department. Upon presentation, it is imperative to determine whether a medical illness, substance use, psychiatric comorbidity, relevant stressors, or nonadherence to treatment could explain the exacerbation. It is also crucial to assess which LAI the patient was given and, if possible, why the patient was started on an LAI (e.g., patient choice, poor adherence, prevention of poor adherence, court order). Determining when the LAI was last administered is essential, as this information will indicate whether the patient had sufficient time to reach therapeutic plasma concentrations. The timing of LAI administration will also reveal whether the patient had sufficient time to stabilize on the LAI before the current exacerbation or relapse. Ascertaining whether the patient missed a dose or received doses with a relevant delay is crucial, because strategies for managing missed doses vary depending on the specific LAI (see Table 3 for specific instructions). To help alleviate psychotic symptoms, it may be possible to give the next LAI dose early (off-label) or to increase the dose, depending on the release properties and dosing windows of the LAI. The HCP should determine whether acute oral supplementation is necessary based on the severity of the acute symptoms. Additional components of the evaluation should include relevant medical history, such as whether the patient presents episodically (exacerbations) or if the patient is always symptomatic (i.e., has residual symptoms), and whether any key medical or psychiatric comorbidities require attention. Identifying current symptoms (e.g., anxiety, depressive, psychotic, self-harm, suicidality), their duration, and whether there has been a significant increase in 
TABLE 3. Management of missed doses for long-acting injectable antipsychotics ${ }^{20,22-24,38,43-46}$

Initiation dosing schedule

Missed initiation

dose

Maintenance dosing schedule

Missed

maintenance dose

\begin{tabular}{|c|c|c|c|c|c|}
\hline \multicolumn{6}{|l|}{ First generation } \\
\hline $\begin{array}{l}\text { Flupenthixol } \\
\text { decanoate }\end{array}$ & $\begin{array}{l}\text { - Patients not previously treated with long-acting } \\
\text { neuroleptics should be given an initial test dose of } 5 \mathrm{mg} \\
(0.25 \mathrm{~mL}) \text { to } 20 \mathrm{mg} \text { (1.0 mL) of Fluanxol Depot } 2 \% \text {. } \\
\text { - An initial dose of } 20 \mathrm{mg}(1.0 \mathrm{~mL} \text { ) of Fluanxol Depot } 2 \% \text { is } \\
\text { usually well tolerated. However, a } 5 \mathrm{mg}(0.25 \mathrm{~mL}) \text { test } \\
\text { dose of Fluanxol Depot } 2 \% \text { is recommended in elderly, } \\
\text { frail, and cachectic patients, and in patients whose } \\
\text { individual or family history suggests a predisposition to } \\
\text { extrapyramidal reactions. } \\
\text { - In the subsequent } 5 \text { to } 10 \text { days, the therapeutic response } \\
\text { and the appearance of extrapyramidal symptoms should } \\
\text { be carefully monitored. } \\
\text { - In patients previously treated with long-acting depot } \\
\text { neuroleptics who displayed good tolerance to these } \\
\text { drugs, an initial dose of } 20 \text { to } 40 \mathrm{mg} \text { ( } 1.0 \text { to } 2.0 \mathrm{~mL} \text { ) of } \\
\text { Fluanxol Depot } 2 \% \text { may be adequate. }\end{array}$ & - Not applicable & \multicolumn{2}{|c|}{$\begin{array}{l}\text { - There is considerable variation in the individual response } \\
\text { of patients to flupenthixol decanoate. Its use for } \\
\text { maintenance therapy requires careful supervision. } \\
\text { - Except in particularly sensitive patients, a second dose of } \\
20 \text { ( } 1.0 \mathrm{~mL}) \text { to } 40 \text { ( } 2.0 \mathrm{~mL}) \text { can be given } 4 \text { to } 10 \text { days } \\
\text { after the initial injection. } \\
\text { - Subsequent dosage adjustments are made in accordance } \\
\text { with the response of the patient, but most patients can } \\
\text { be adequately controlled by } 20 \text { to } 40 \mathrm{mg}(1.0 \text { to } 2.0 \mathrm{~mL}) \\
\text { every } 2 \text { to } 3 \text { weeks. }\end{array}$} & - No data \\
\hline $\begin{array}{r}\text { Fluphenazine } \\
\text { decanoate }\end{array}$ & $\begin{array}{l}\text { - For most patients, a dose of } 12.5-25 \mathrm{mg}(0.5-1.0 \mathrm{~mL}) \\
\text { may be given to initiate therapy. Patients with no history } \\
\text { of taking phenothiazines should be treated initially with } \\
\text { a shorter-acting form of fluphenazine before } \\
\text { administering the decanoate to determine the patient's } \\
\text { response to fluphenazine and to establish appropriate } \\
\text { dosage. }\end{array}$ & - Not applicable & \multicolumn{2}{|c|}{$\begin{array}{l}\text { - The appropriate dosage of fluphenazine decanoate } \\
\text { injection should be individualized for each patient and } \\
\text { responses should be carefully monitored. No precise } \\
\text { formula can be given to convert to use of a fluphenazine } \\
\text { decanoate injection. } \\
\text { - A study showed that } 20 \mathrm{mg} \text { fluphenazine hydrochloride } \\
\text { daily was equivalent to } 25 \mathrm{mg}(1 \mathrm{~mL}) \text { of fluphenazine } \\
\text { decanoate injection every } 3 \text { weeks. This represents an } \\
\text { approximate conversion ratio of } 12.5 \mathrm{mg}(0.5 \mathrm{~mL}) \text { of } \\
\text { decanoate every } 3 \text { weeks for every } 10 \mathrm{mg} \text { of fluphenazine } \\
\text { hydrochloride daily. } \\
\text { - Dosage should not exceed } 100 \mathrm{mg} \text {. If doses }>50 \mathrm{mg} \text { are } \\
\text { deemed necessary, the next dose and succeeding doses } \\
\text { should be increased cautiously in increments of } \\
12.5 \mathrm{mg} \text {. }\end{array}$} & - No data \\
\hline $\begin{array}{l}\text { Haloperidol } \\
\text { decanoate }\end{array}$ & $\begin{array}{l}\text { - Administer 10-20 times the previous daily dose in oral } \\
\text { haloperidol equivalents, depending on the patient's age, } \\
\text { clinical history, physical condition, and response to } \\
\text { previous antipsychotic therapy. } \\
\text { - Should not exceed } 100 \mathrm{mg} \text { regardless of previous } \\
\text { antipsychotic dose requirements }\end{array}$ & - Not applicable & \multicolumn{2}{|c|}{$\begin{array}{l}\text { - Administer } 10-15 \text { times the previous daily dose in oral } \\
\text { haloperidol equivalents, depending on the patient's age, } \\
\text { clinical history, physical condition, and response to } \\
\text { previous antipsychotic therapy. }\end{array}$} & - No data \\
\hline $\begin{array}{c}\text { Zuclopenthixol } \\
\text { decanoate }\end{array}$ & $\begin{array}{l}\text { - For patients taking oral zuclopenthixol up to } 20 \mathrm{mg} \text { daily, } \\
25-40 \mathrm{mg} \text { daily, 50-75 mg daily, or }>75 \mathrm{mg} \text { daily, the } \\
\text { suggested zuclopenthixol decanoate doses are } 100 \mathrm{mg} \\
\text { twice weekly, } 200 \mathrm{mg} \text { twice weekly, } 300 \mathrm{mg} \text { twice weekly, } \\
\text { and } 400 \mathrm{mg} \text { twice weekly, respectively. } \\
\text { - For patients receiving zuclopenthixol acetate } 50 \mathrm{mg} \text {, } \\
100 \mathrm{mg} \text {, or } 150 \mathrm{mg} \text {, the suggested zuclopenthixol } \\
\text { decanoate doses are } 100 \mathrm{mg} \text { twice weekly, } 200 \mathrm{mg} \text { twice } \\
\text { weekly, and } 300 \mathrm{mg} \text { twice weekly, respectively. }\end{array}$ & - Not applicable & \multicolumn{2}{|c|}{$\begin{array}{l}\text { - Administer } 150-300 \mathrm{mg} \text { intramuscularly every } \\
\text { 2-4 weeks. } \\
\text { - Some patients may require higher or lower doses, or } \\
\text { shorter intervals between doses. }\end{array}$} & - No data \\
\hline \multicolumn{6}{|c|}{ Second generation } \\
\hline $\begin{array}{l}\text { Aripiprazole } \\
\text { lauroxil } \\
\quad\left(\text { Aristada }{ }^{\circledR}\right)\end{array}$ & $\begin{array}{l}\text { - Treatment can be initiated at - Not applicable } \\
\text { a dose of } 441 \mathrm{mg} \text { (deltoid or } \\
\text { gluteal), } 662 \mathrm{mg} \text { (gluteal), } \\
\text { or } 882 \mathrm{mg} \text { (gluteal) } \\
\text { administered monthly } \\
\text { (which correspond to } 300 \text {, } \\
450 \text {, and } 600 \mathrm{mg} \text {, } \\
\text { respectively) } \\
\text { - Treatment may also be } \\
\text { initiated with the } 882 \mathrm{mg} \\
\text { dose every } 6 \text { weeks or with }\end{array}$ & $\begin{array}{r}\text { - } 441 \mathrm{~m} \\
\text { glute } \\
\text { - } 662 \mathrm{~m} \\
\text { - } 882 \mathrm{~m} \\
\text { in gl } \\
\text { - } 1064 \mathrm{n} \\
\text { glute } \\
\text { - For pa } \\
\text { stabi } \\
\text { aripi } \\
\text { mont }\end{array}$ & $\begin{array}{l}\text { monthly in deltoid or } \\
\text { monthly in gluteal } \\
\text { teal muscle } \\
\text { g every } 2 \text { months in } \\
\text { ients who are } \\
\text { ized on } 10 \mathrm{mg} / \mathrm{d} \text { oral } \\
\text { razole, use } 441 \mathrm{mg} \\
\text { ly; for those stabilized }\end{array}$ & $\begin{array}{l}\text {-When a dose is missed, administer } \\
\text { soon as possible. } \\
\text { - For patients taking } 441 \mathrm{mg} \text { monthl } \\
\text { time since the last injection was } \\
\text { supplementation is required; if }> \\
\text { supplement with } 7 \text { days of oral a } \\
\text { if }>7 \text { weeks, supplement with } 21 \\
\text { aripiprazole. } \\
\text { - For patients taking } 662 \text { mg monthl } \\
\text { time since the last injection was } \\
\text { supplementation is required; if }>\end{array}$ & $\begin{array}{l}\text { the next injection as } \\
\text { ly, if the length of } \\
\leq 6 \text { weeks, no oral } \\
6 \text { and } \leq 7 \text { weeks, } \\
\text { ripiprazole; } \\
1 \text { days of oral } \\
\text { ly, if the length of } \\
\leq 8 \text { weeks, no oral } \\
8 \text { and } \leq 12 \text { weeks, }\end{array}$ \\
\hline
\end{tabular}


TABLE 3. Continued

$1064 \mathrm{mg}$ dose every

2 months.

- In conjunction with the first dose, administer treatment with oral aripiprazole for 21 consecutive days. on $15 \mathrm{mg} / \mathrm{d}$ oral aripiprazole, use $662 \mathrm{mg}$ monthly, $822 \mathrm{mg}$ every 6 weeks, or $1064 \mathrm{mg}$ every 2 months; for • For patients taking $882 \mathrm{mg}$ monthly (or every 6 weeks), those stabilized on $20 \mathrm{mg} / \mathrm{d}$ or higher oral aripiprazole use $882 \mathrm{mg}$ monthly.

supplement with 7 days of oral aripiprazole; if $>12$ weeks, supplement with 21 days of oral aripiprazole.

if the length of time since the last injection was $\leq 8$ weeks, no oral supplementation is required; if $>8$ and $\leq 12$ weeks, supplement with 7 days of oral aripiprazole; if $>12$ weeks, supplement with 21 days of oral aripiprazole.

- For patients taking $1064 \mathrm{mg}$ every 2 months, if the length of time since the last injection was $\leq 10$ weeks, no oral supplementation is required; if $>10$ and $\leq 12$ weeks, supplement with 7 days of oral aripiprazole; if $>12$ weeks, supplement with 21 days of oral aripiprazole.

- If the second or third doses are missed: If $>4$ weeks and $<5$ weeks have elapsed since the last injection, administer the injection as soon as possible.

maintenance dose is

$400 \mathrm{mg}$ monthly (deltoid/ gluteal). If there are adverse - If $>5$ weeks have elapsed since the last injection, reactions with the $400 \mathrm{mg}$ dose, consider reducing the dosage to $300 \mathrm{mg}$ monthly. - Administer no sooner than 26 days after the previous injection.

aripiprazole), continue treatment with the antipsychotic for 14 consecutive days.

Olanzapine During the first 8 weeks:

- Not applicable Target oral dose of $10 \mathrm{mg} / \mathrm{d}$ requires $210 \mathrm{mg} / 2$ wk or $405 \mathrm{mg} / 4$ wk; target oral dose of 15 or $20 \mathrm{mg} / \mathrm{d}$ requires $300 \mathrm{mg} / 2 \mathrm{wk}$.

PP1M (Invega

Schizophrenia and schizoaffective disorder (deltoid)

- Day 1: $234 \mathrm{mg}$

- Day 8: $156 \mathrm{mg}$
After the initial 8 weeks:

- Initial target oral dose of $10 \mathrm{mg} / \mathrm{d}$ requires $150 \mathrm{mg} / 2$ wk or $300 \mathrm{mg} / 4$ wk following initiation.

- Initial target oral dose of $15 \mathrm{mg} / \mathrm{d}$ requires $210 \mathrm{mg} / 2$ wk or $405 \mathrm{mg} / 4$ wk following initiation.

- Initial target oral dose of $20 \mathrm{mg} / \mathrm{d}$ requires $300 \mathrm{mg} / 2$ wk following initiation.

- Schizophrenia (deltoid or gluteal)

- Monthly: 39-234 mg (recommended dose $117 \mathrm{mg}$ )

- Schizoaffective disorde (deltoid or gluteal) - Monthly: 78-234 mg (based on tolerability) restart concomitant oral aripiprazole for 14 days with the next administered injection.

- If the fourth or subsequent doses are missed: If $>4$ weeks and $<6$ weeks have elapsed since the last injection, administer the injection as soon as possible; if $>6$ weeks have elapsed since the last injection, restart concomitant oral aripiprazole for 14 days with the next administered injection. - No data

- Patients may receive dose 7 days before or after the monthly dose timepoint

-4-6 weeks since last injection: Resume regular dosing at previously stabilized dose as soon as possible.

- $>6$ weeks to 6 months since last injection: Resume the
- Patients may be given the second initiation dose 4 days before or after the 1 -week timepoint.

$\bullet<4$ weeks since firs injection: Second dose should be administered as soon as possible.

-4-7 weeks since first injection: Administer deltoid (156 mg) as soon as possible, followed by second injection (deltoid) 1 week later, then resume regular monthly dosing (deltoid or gluteal).

$\bullet>7$ weeks since first injection: Administe $234 \mathrm{mg}$ on day 1 , followed by $156 \mathrm{mg} 1$ week later (deltoid), then resume regular monthly dosing (deltoid or gluteal). same dose the patient was previously stabilized on (unless the patient was stabilized on a dose of $234 \mathrm{mg}$, then the first 2 injections should each be $156 \mathrm{mg}$ ) in the following manner: Administer a deltoid injection as soon as possible. Then administer a second deltoid injection 1 week later at the same dose. Thereafter, resume administering the previously stabilized dose in the deltoid or gluteal 1 month after the second injection.

->6 months after last injection: Restart with recommended initiation dosing schedule followed by maintenance schedule dosing. 
TABLE 3. Continued

\begin{tabular}{|c|c|c|c|c|}
\hline $\begin{array}{l}\text { PP3M (Invega } \\
\text { Trinza }^{\circledR} \text { ) }\end{array}$ & $\begin{array}{l}\text { - Initiate at } 273,410,546 \text {, or } \\
819 \mathrm{mg} \text { doses every } \\
3 \text { months, if patients were } \\
\text { adequately treated with } \\
\text { Invega Sustenn } \mathrm{a}^{\circledR} \text { at } 78, \\
117,156, \text { or } 234 \mathrm{mg} \text {, } \\
\text { respectively, for at least } \\
4 \text { months. The last two } \\
\text { Invega Sustenn }{ }^{\circledR} \text { doses } \\
\text { should be the same before } \\
\text { the transition to Invega } \\
\text { Trinza }{ }^{\circledR} \text {. }\end{array}$ & $\begin{array}{l}\text { - PP3M may be administered up } \\
\text { to } 7 \text { days before or after the } \\
\text { monthly timepoint of the } \\
\text { next scheduled PP1M dose. }\end{array}$ & $\begin{array}{l}\text { - Once every } 3 \text { months: } 273 \text {, } \\
\text { 410, } 546, \text { or } 819 \mathrm{mg} \\
\text { (deltoid/gluteal) }\end{array}$ & $\begin{array}{l}\text { - Patients may be given the injection } 2 \text { weeks before or } \\
\text { after the } 3 \text {-month timepoint. } \\
\text { - } 3.5 \text { to }<4 \text { months since last injection: Previously } \\
\text { administered dose should be given as soon as } \\
\text { possible, then resume maintenance schedule dosing. } \\
\text { - } 4 \text { to } 9 \text { months since last injection: If the last dose of } \\
\text { PP3M was } 273,410,546 \text {, or } 819 \mathrm{mg} \text {, administer } \\
\text { (deltoid) PP1M } 78,117,156 \text {, or } 156 \mathrm{mg} \text { on days } 1 \text { and } \\
\text { 8, respectively. One month following day } 8 \text {, } \\
\text { administer (deltoid or gluteal) PP3M } 273,410,546 \text {, or } \\
819 \mathrm{mg} \text {, respectively, and resume maintenance } \\
\text { schedule dosing. } \\
\text { - >9 months since last injection: Reinitiate treatment } \\
\text { with PP1M per prescribing information. After } \\
\text { adequate treatment for } \geq 4 \text { months, PP3M treatment } \\
\text { may be resumed. }\end{array}$ \\
\hline $\begin{array}{l}\text { Risperidone LAl } \\
\quad \text { (Risperdal } \\
\left.\text { Consta }{ }^{\circledR}\right)\end{array}$ & $\begin{array}{l}\text { - } 12.5,25,37.5 \text {, or } 50 \mathrm{mg} \text { vial } \\
\quad \text { kits }\end{array}$ & - Not applicable & $\begin{array}{l}\text { - } 25 \mathrm{mg} \text { should be administered } \\
\text { every } 2 \text { weeks (deltoid or } \\
\text { gluteal). Maximum dose } \\
\text { should not exceed } 50 \mathrm{mg} \\
\text { every } 2 \text { weeks. }\end{array}$ & - No data to address reinitiation \\
\hline
\end{tabular}

$\mathrm{LAI}=$ long-acting injectable; PP1M = paliperidone palmitate once monthly; PP3M = paliperidone palmitate once every 3 months.

psychopathology will also help guide management. Certain lifestyle factors may also be relevant, such as (in the case of olanzapine LAI) smoking. ${ }^{30}$ A list of pertinent questions that could be posed to the patient, caregiver, or HCP is summarized in Table 4.

Table 4 also summarizes actions that the clinician should consider based on the response to these questions and whether the corresponding features may be related to breakthrough psychotic symptoms. Figure 1 shows a decision tree regarding adaptation of management strategies for symptom breakthrough in patients receiving an LAI. For example, potential causes of breakthrough psychotic symptoms that may need to be addressed can include treatment nonadherence to LAIs, OAPs, non-antipsychotic comedications, and inappropriate or inadequate dosing, including initiating treatment incorrectly and other medication errors. Other causes of breakthrough psychotic symptoms can include AEs; treatment resistance or failure; alcohol or drug abuse or misuse; possible stressors present in the patient's life, including legal issues; and/or psychosocial issues unrelated to relapse, including unstable living conditions, financial pressures, and stressors induced by the family environment, caregivers, or workplace. Difficulties accessing treatments or care would further complicate the management of breakthrough psychotic symptoms and should be improved or resolved if possible. In cases where substance abuse is a contributing factor to breakthrough symptoms, symptomatic management with either OAPs or benzodiazepines can be implemented until concentrations of the offending drug decrease. Psychoeducation and referral for substance abuse treatment can also be considered. If the symptom exacerbation is not caused by pharmacologic issues, then nonpharmacologic resolutions should be evaluated and sought. For example, therapy and family treatment sessions, lifestyle coaching, cognitive behavior therapy and rehabilitation, and acute pharmacologic support may still be necessary. If the etiology of the breakthrough symptoms is pharmacologic, the clinician should work to determine the efficacy of the patient's treatment. The clinician should also consider whether the optimal dosage is being used and whether the efficacy outcome is sufficient (and in which domains). Some patients may require higher or lower doses to obtain optimal benefit, or they may require shorter intervals between doses (offlabel). However, caution should be exercised to avoid overdosing and underdosing. Because higher doses may increase the incidence of AEs, regular and continuous supervision and reassessment is considered essential to identify and maintain the lowest dose level that is compatible with adequate symptom control. It is important to consult the prescribing information for LAIs for their recommended dosing; drug manufacturers can also be contacted for additional information on file, if needed (Table 1).

If causal factors for symptom exacerbation cannot be identified quickly enough, the addition of an OAPideally the same agent given in the LAI formulationmay be needed as an acute measure (Figure 1). The benefit of adding a different antipsychotic, although done frequently in clinical care, is not supported by highlevel evidence based on randomized controlled trials. ${ }^{31-33}$ This even seems to apply to clozapine, for which there is limited and inconsistent evidence of benefit when included as part of a polypharmacy 
TABLE 4. Key questions asked by health-care providers to ascertain the etiology of breakthrough symptoms

Potential factors
contributing to
breakthrough
symptoms

Substance abuse

stressors

Poor adherence to

medication

Comorbidities

Proper LAI dose and administration

Pharmacokinetics and pharmacodynamics

Adverse events
1. Has the patient been using any medications or substances differently than prescribed?

2. Has the patient been using any medications or substances that are not prescribed?

1. Has the patient experienced any recent abuse or trauma?

2. Has the patient experienced any life-changing events?

1. Has the patient missed any doses?

2. When was his/her last scheduled injection? Did he/she receive it on time?

3. Does the patient believe that the LAI medication is helping him/her to feel better?

4. Has stigma contributed to a gap in treatment?

5. Is cost/access/transportation an issue?

1. Does the patient take other, adjunctive antipsychotic medications? - Consider adjusting LAl dose upward or potentially shortening the injection a. If yes, what are the medications, and at what dose/frequency are they taken?

b. Has the patient been adherent with these medications?

2. Does the patient take other medications for any medical comorbidities?

a. If yes, what are the medications, and at what dose/frequency are they taken?

b. Has the patient been adherent with these medications?

c. Has the patient seen any other health-care professionals since his/her last visit here?

1. When was the LAl initiated?

2. How was it initiated?

3. How many injections were given since initiation?

4. Where was the injection given (deltoid or gluteal/left or right)?

5. Can proper LAI preparation be clarified (e.g., shaking properly, needle selection)?

6 . Is the patient morbidly obese?

1. What LAl antipsychotic medication is the patient currently receiving (ascertain formulation of LAl antipsychotic)?

2. What is the last prescribed dose of LAl antipsychotic medication given?

3. Is the patient receiving other medications, including OAP supplementation (What drug? Dose? Frequency? Adherence to oral?)

4. Do certain comedications or habits (smoking) affect the hepatic first pass metabolism of the LAl antipsychotic in a relevant way?

5. When was the patient's last LAl antipsychotic medication injection?

6. When is/was the next injection due?

7. What is the usual interval between doses?

8. How many injections were given since LAl initiation?

9. Where are the injections administered (e.g., home, clinic, pharmacy, medical center)?

10. Does the patient usually develop breakthrough psychotic symptoms during the injection cycle and, if so, at what timepoint during the injection cycle?

1. What AEs are the patient experiencing? How severe are the AEs?

2. New or ongoing? Are they related to the LAI?
Provide psychoeducation about negative effects of substance use; instruction to not skip or stop medications when using substances (unless explicitly instructed by prescriber); and/or referral to substance abuse treatment.

Provide psychotherapy and/or trauma-focused therapy.

- Provide psychoeducation about utility of LAls and negative effects of nonadherence; and/or outreach to patient or family member the day before the time of next scheduled injection or after missed treatment.

- Identify and address problems with illness insight, self-stigma, or stigma by others interfering with the treatment; assist with access/transportation; consider home visit and in-home treatment.

Consider adjusting LAI dose upward or potentially
interval to make adjunctive OAPs superfluous.

- Provide psychoeducation about negative effects of nonadherence; consider supervised oral medication intake if feasible.

- Address psychiatric comorbidities, including with psychotherapeutic and psychosocial as well as lifestyle interventions, if applicable.

- Address medical comorbidities, including with lifestyle interventions, if applicable.

Consider deltoid injection to achieve higher antipsychotic blood levels; ensure that LAI was properly stored, constituted, or reconstituted; ensure the needle length is adequate for deep intramuscular injection in case of obesity (or switch to deltoid).

- Consider adjusting LAI dose upward or potentially shortening the injection interval to make adjunctive OAPs superfluous.

- Consider remaining time needed to reach steady state, requiring temporary dose increase and/or adjunctive OAP treatment.

- Consider drug-drug interactions: In case comedication(s) increase the LAI metabolism and thereby decrease the antipsychotic blood level, consider increasing LAI dose, or shortening of the injection interval (off-label), or stopping/switching that comedication (e.g., carbamazepine, smoking for olanzapine LAI); in case comedication(s) decrease the LAI metabolism and thereby increase the antipsychotic blood level (manifesting as parkinsonism-related secondary negative symptoms or akathisia manifesting as agitation), consider decreasing LAl dose, adding medications to treat the $A E$ (e.g., parkinsonism or akathisia), or stopping/switching that comedication (e.g., fluoxetine or paroxetine for risperidone LAl, or fluvoxamine for olanzapine LAI).

- Identify degree of distress, dysfunction, or medical risk associated with the AE. - Consider drug-drug interactions if comedications inhibit the same cytochrome P450 system that metabolizes the LAI (e.g., lower LAl dose) or add medications reducing these side effects (anticholinergics, beta-blockers, benzodiazepines), or decrease the dose or stop/switch the comedication(s) slowing the metabolisms of the LAl antipsychotic.

- Consider managing the AE with an additional medication or lifestyle change, if feasible. 
regimen. ${ }^{32,34}$ The coadministration of an OAP with an LAI formulation of the same antipsychotic should be intended as a transient measure (off-label), and the efficacy and safety of this strategy should be assessed within 1 to 2 weeks. However, caution should be exercised with this strategy, because data on the safety of concomitant use of LAI and OAPs are limited, especially over extended periods of time. If addition of the OAP is successful, the time of regained stability can be used to adjust the LAI administration, dose, or dosing interval (off-label) to optimize LAI treatment; to adjust pharmacologic or nonpharmacologic treatments for the core disorder or comorbidities; or to address any other identified reason for symptom exacerbation. If the patient is sufficiently stable, a slow taper of the OAP can be attempted. If addition of the OAP and concurrent optimization of the LAI antipsychotic treatment do not sufficiently stabilize the patient, if symptoms reappear after stopping the OAP, or if other potential causes cannot be identified or addressed adequately, the patient may not be responding to treatment, and a switch of the adjunctive OAP or switch of the LAI may need to be considered.

During this entire process, it is critical that there be appropriate communication among treatment providers, the patient, the patient's family or partner, and HCPs in different treatment settings (if the patient requires stabilization in an inpatient setting). Furthermore, the multidisciplinary nature of treating patients with schizophrenia highlights the importance of organizations and disciplines working as a team. For example, a patient with schizophrenia often receive care from multiple psychiatric teams (i.e., inpatient setting, community mental health, and crisis home treatment teams) as well as a general practitioner. Therefore, information pertaining to a patient's condition and treatment should be readily communicated among these HCPs. ${ }^{35}$ The treatment plan and details about LAI administration with or without OAP supplementation, the goals and steps of further management of the OAP, and any other aspect of the management should be clearly communicated with the patient and everyone involved in his or her care.

If the patient was stabilized in an inpatient setting, a discharge checklist could be used to facilitate communication and minimize the risk of future breakthrough psychosis or symptomatic worsening (Figure 2). Details regarding the stabilization, including the source of the problem, intervention, and follow-up, should be noted in the patient's medical record and communicated to the patient and to his or her caregivers and HCPs. Medication reconciliation and discussion of, and agreement with, a recovery plan with all HCPs should be carried out. The patient and caregiver(s) should be provided with clear, detailed outpatient discharge instruction. Importantly, continuity of care should be facilitated by sharing the recovery plan with the patient's current HCPs. Counseling and reflection with the patient and caregivers on the cause and consequences of this exacerbation would be advantageous to the patient's outcome. Furthermore, combining nonpharmacologic with pharmacologic interventions, such as discussing the patient's goals and how to prevent a future episode of breakthrough symptoms, can benefit the patient by helping him or her to achieve goals and improve overall prognosis.

\section{Future Directions and Limitations}

It should be noted that the recommendations provided in this article are based on available clinical, PK, and dosing data that are supplemented with clinical experience. The recommendations do not represent a formal consensus statement and therefore were not subjected to the explicit methodology commonly used to identify areas of agreement and disagreement among experts. The paucity of data regarding management strategies in response to patients experiencing breakthrough symptoms while undergoing LAI treatment underscores the need for future research, and in particular well-designed studies that examine the outcome of increasing LAI dose, switching LAIs, or supplementing the LAI with a low dose of the corresponding oral formulation in patients with symptom exacerbation. As such data become available, it is hoped that a formal guideline-consensus process based on a broader evidence base that may change or sharpen the currently made recommendations will be possible.

\section{Summary}

This article provides a framework and action plan for HCPs who manage patients treated with LAI antipsychotics who present with breakthrough psychosis and symptomatic worsening. Management options aimed at optimizing the disease prognosis and patient outcome include first ruling out or addressing medical or substance use as a contributing factor, identifying and addressing potential stressors, optimizing nonpharmacologic treatments, treating medical and psychiatric comorbidities, ensuring proper LAI administration technique, addressing missed LAI doses or lack of steady state, and increasing the dose of LAIs or shortening their injection intervals (off-label). If these strategies do not work sufficiently with frequent monitoring for efficacy and safety, supplementing the LAI with a low dose of the corresponding OAP formulation for fast symptom control may need to be considered (off-label). Caution should be exercised with this strategy, because data on the safety of concomitant use of LAI and OAPs are limited, especially over extended periods of time. If symptoms abate, optimizing the LAI therapy and addressing any other 


\section{Hospital Discharge Checklist for Patients With Schizophrenia}

\section{CURRENT STATUS}

1. LAI antipsychotic treatment history (check all that apply):

Ocurrent OLifetime OBefore admission
ODuring hospitalization OPlanned after discharge ONA

2. If the patient receives an LAI antipsychotic now, complete Table for most recent 3 doses (if known):

\begin{tabular}{|c|c|c|c|c|c|}
\hline LAI NAME (please check) & DATE & DOSE (mg) & NEEDLE SIZE & IM LOCATION & IM Interval \\
\hline $\begin{array}{l}\text { OARI-M OARI-L OFLU-D OHAL-D } \\
\text { OLA-P OPP1M OPP3M ORLAI }\end{array}$ & & & & $\begin{array}{l}\text { OGluteal } \\
\text { ODeltoid }\end{array}$ & \\
\hline $\begin{array}{l}\text { OARI-M OARI-L OFLU-D OHAL-D } \\
\text { OOLA-P OPP1M OPP3M ORLAI }\end{array}$ & & & & $\begin{array}{l}\text { OGluteal } \\
\text { ODeltoid }\end{array}$ & \\
\hline $\begin{array}{l}\text { OARI-M OARI-L OFLU-D OHAL-D } \\
\text { OLA-P OPP1M OPP3M ORLAI }\end{array}$ & & & & $\begin{array}{l}\text { OGluteal } \\
\text { ODeltoid }\end{array}$ & \\
\hline
\end{tabular}

Legend: aripiprazole monohydrate (ARI-M), aripiprazole lauroxil (ARI-L), fluphenazine decanoate (FLU-D), haloperidol decanoate (HAL-D), olanzapine pamoate (OLA-P), paliperidone palmitate once monthly (PP1M), paliperidone palmitate every 3 months (PP3M),

risperidone long-acting injection (RLAI)

3. Is the patient currently receiving oral antipsychotic supplementation? YES NO
a. If yes, list antipsychotic name(s)
b. Dose
c. Duration to date

4. Target symptoms (check all that apply): OAgitation/Aggression ODelusions

OHallucinations ONonadherence Oother:

5. Known stressors associated with hospitalization

6. Any adverse effects potentially associated with LAI treatment?
a. EPS
b. Sedation
YES O NO O
c. Anxiety
YES O NO O
YES O NO O
d. Insomnia
YES O NOO
e. Prolactin elevation-related side effects
YES O NO O
f. Akathisia
YES O NO
g. Other (specify):

7. Interventions to address AEs? During hospitalization Postdischarge $O$ N/A

- Dose adjustments (specify):

- Names (dose) of adjunctive medications:

FIGURE 2. Hospital discharge checklist for patients with schizophrenia. 


\section{Hospital Discharge Checklist for Patients With Schizophrenia}

8. Comedication with inducers/inhibitors?

YES O NO O

1. Dose adjustments (specify):

2. Names (dose) of inducer/inhibitor:

\section{POSTDISCHARGE PLAN}

9. Is LAI planned after discharge: $\bigcirc$ Continuation $\bigcirc$ New initiation $\bigcirc$ No

a. If continuation or new initiation, complete the table for the next planned 3 injections:

\begin{tabular}{|c|c|c|c|c|c|}
\hline LAI NAME (please check) & DATE & DOSE (mg) & NEEDLE SIZE & IM LOCATION & IM Interval \\
\hline $\begin{array}{l}\text { OARI-M OARI-L OFLU-D OHAL-D } \\
\text { OLA-P OPP1M OPP3M ORLAI }\end{array}$ & & & & $\begin{array}{l}\text { OGluteal } \\
\text { ODeltoid }\end{array}$ & \\
\hline $\begin{array}{l}\text { OARI-M OARI-L OFLU-D OHAL-D } \\
\text { OLA-P OPP1M OPP3M ORLAI }\end{array}$ & & & & $\begin{array}{l}\text { OGluteal } \\
\text { ODeltoid }\end{array}$ & \\
\hline $\begin{array}{l}\text { OARI-M OARI-L OFLU-D OHAL-D } \\
\text { OLA-P OPP1M OPP3M ORLAI }\end{array}$ & & & & $\begin{array}{l}\text { OGluteal } \\
\text { ODeltoid }\end{array}$ & \\
\hline
\end{tabular}

Legend: aripiprazole monohydrate (ARI-M), aripiprazole lauroxil (ARI-L), fluphenazine decanoate (FLU-D), haloperidol decanoate (HAL-D), olanzapine pamoate (OLA-P), paliperidone palmitate once monthly (PP1M), paliperidone palmitate every 3 months PP3M), risperidone long-acting injection (RLAI)

10. Is the next $\operatorname{LAI}(\mathrm{s})$ scheduled?

YES O NO O

a. With whom (prescriber's / nurse's name) and location (clinic/address)

b. Contact person (phone, address and e-mail address)

11. Oral antipsychotic supplementation? Current $\bigcirc$ New initiation $O$ No
a. Continuation dose/duration
b. Taper schedule
c. Anticipated stop date

12. Discharge to past location?

YES O NO O

a. If no, explain

FIGURE 2. Continued. 


\section{Hospital Discharge Checklist for Patients With Schizophrenia}

\section{POSTDISCHARGE PLAN}

13. Discharge to current provider?

YES O NO O

a. If no, explain

14. Court-mandated treatment

YES O NO O

a. Enforced?

YES O NO O

15. Goal of treatment

16. Patient's attitude to LAI:

Positive

Neutral

Apprehensive

Negative

17. Attitude of family members to LAI:

Positive

Neutral

Apprehensive

Negative

COMMENTS:

FIGURE 2. Continued

factors potentially related to the symptomatic exacerbation should be continued, and slowly discontinuing the OAP can be attempted. If symptoms continue or worsen despite addition of the OAP, if symptoms recur after stopping the OAP, and/or if addressing other factors potentially related to the breakthrough symptoms is insufficient, it may be necessary to switch the OAP or the LAI. However, regardless of the management plan, it must be documented and communicated clearly so that continuity of care is assured. Any strategies that are successful in restabilizing patients receiving LAI antipsychotic therapy who presented with breakthrough psychosis or symptomatic worsening should be retained and repeated in the event of future destabilization.

\section{Acknowledgments}

The authors thank Matthew Grzywacz, PhD, Shaylin Shadanbaz, $\mathrm{PhD}$, and Lynn Brown, $\mathrm{PhD}$, for their writing and editorial assistance, which is supported by Janssen Scientific Affairs LLC.

\section{Funding}

This study was funded by Janssen Scientific Affairs LLC. 


\section{Disclosures}

Christoph Correll is on the boards of Alkermes, IntraCellular Therapies, Janssen/Johnson and Johnson, Lundbeck, Neurocrine, Otsuka, Pfizer, Sunovion, and Teva. He holds consultancy positions with Alkermes, Allergan, the Gerson Lehman Group, IntraCellular Therapies, Janssen/Johnson and Johnson, LB Pharma, Lundbeck, Medscape, Neurocrine, Otsuka, Pfizer, Rovi, Sunovion, Takeda, and Teva, and has provided expert testimony for Bristol-Myers Squibb, Janssen, and Otsuka. He has received grants or has grants pending from Janssen, Neurocrine, Patient Centered Outcomes Research Institute, the American Academy of Child and Adolescent Psychiatry, the Bendheim Foundation, Takeda, and the Thrasher Foundation; he has received payment for lectures, including service on speakers bureaus, from Janssen/Johnson and Johnson, Lundbeck, Otsuka, Pfizer, Sunovion, and Takeda; and he has received payment for manuscript preparation from Medscape. In addition, travel, accommodations, meeting, and other expenses unrelated to the activities listed have been paid to Dr. Correll.

Jennifer Kern Sliwa reports personal fees from Johnson \& Johnson and personal fees from Johnson \& Johnson, outside the submitted work.

Dean Najarian reports personal fees from Johnson and Johnson and personal fees from Johnson and Johnson, outside the submitted work.

Stephen Saklad has received personal fees and acted as a consultant for Alkermes, Otsuka/Lundbeck, Jazz, NCS Pearson, and Takeda. He also sits on the advisory boards of and has delivered lectures for Alkermes, Neurocrine, and Otsuka/Lundbeck. He is a committee member (no financial support) of the College of Psychiatric and Neurologic Pharmacists (CPNP), and a board member and Treasurer of the College of Psychiatric and Neurologic Pharmacists Foundation (CPNPF).

\section{Supplementary materials}

To view supplementary material for this article, please visit https://doi.org/10.1017/S1092852918001098

\section{REFERENCES:}

1. Brissos S, Veguilla MR, Taylor D, Balanza-Martinez V. The role of long-acting injectable antipsychotics in schizophrenia: a critical appraisal. Ther Adv Psychopharmacol. 2014; 4(5): 198-219.

2. Correll CU, Citrome L, Haddad PM, et al. The use of long-acting injectable antipsychotics in schizophrenia: evaluating the evidence. J Clin Psychiatry. 2016; 77(suppl 3): 1-24.

3. Barnes TR, Shingleton-Smith A, Paton C. Antipsychotic long-acting injections: prescribing practice in the UK. Br J Psychiatry Suppl. 2009; 52:S37-S42.

4. Patel MX, Taylor M, David AS. Antipsychotic long-acting injections: mind the gap. Br J Psychiatry Suppl. 2009; 52: S1-S4.
5. Weiden PJ, Kim E, Bermak J, et al. Does half-life matter after antipsychotic discontinuation. A relapse comparison in schizophrenia with three different formulations of palperidone. J Clin Psychiatry. 2017; 78(7): e813-e820.

6. Samtani MN, Sheehan JJ, Fu DJ, et al. Management of antipsychotic treatment discontinuation and interruptions using model-based simulations. Clin Pharmacol. 2012; 4:25-40.

7. Bosanac P, Castle DJ. Why are long-acting injectable antipsychotics still underused? BJPsych Advances. 2016; 21: 98-105.

8. Kane JM, Kishimoto T, Correll CU. Assessing the comparative effectiveness of long-acting injectable vs. oral antipsychotic medications in the prevention of relapse provides a case study in comparative effectiveness research in psychiatry. J Clin Epidemiol. 2013; 66(suppl 8): S37-S41.

9. Kishimoto T, Nitta M, Borenstein M, et al. Long-acting injectable versus oral antipsychotics in schizophrenia: a systematic review and meta-analysis of mirror-image studies. J Clin Psychiatry. 2013; 74 (10): 957-965.

10. Citrome L. New second-generation long-acting injectable antipsychotics for the treatment of schizophrenia. Expert Rev Neurother. 2013; 13(7): 767-783.

11. Llorca PM, Abbar M, Courtet P, et al. Guidelines for the use and management of long-acting injectable antipsychotics in serious mental illness. BMC Psychiatry. 2013; 13: 340.

12. Marder SR, Conley R, Ereshefsky L, et al. Clinical guidelines: dosing and switching strategies for long-acting risperidone. J Clin Psychiatry. 2003; 64(suppl 16): 41-46.

13. Keith SJ, Kane JM, Turner M, et al. Academic highlights: guidelines for the use of long-acting injectable atypical antipsychotics. J Clin Psychiatry. 2004; 65(1): 120-131.

14. Baldelli S, Clementi E, Cattaneo D. Can we rely on AGNP therapeutic targets also for LAI antipsychotics? Pharmacopsychiatry. 2017; doi: 10.1055/s-0043-122603. [Epub ahead of print]. PMID: 29179228.

15. Hiemke C, Bergemann N, Clement HW, et al. Consensus guidelines for therapeutic drug monitoring in neuropsychopharmacology: update 2017. Pharmacopsychiatry 2018; 51(1-02):e1.

16. Porcelli S, Bianchini O, De GG, et al. Clinical factors related to schizophrenia relapse. Int J Psychiatry Clin Pract. 2016; 20(2): 54-69.

17. Saklad SR. Paliperidone palmitate: Adjusting dosing intervals and measuring serum concentrations. Curr Psychiatry. 2018; 17(8): 45-55.

18. Knox ED, Stimmel GL Clinical review of a long-acting, injectable formulation of risperidone. Clin Ther. 2004; 26(12): 1994-2002.

19. Remington GJ, Adams ME. Depot neuroleptic therapy: clinical considerations. Can J Psychiatry. 1995; 40(3 suppl 1): S5-S11.

20. Alkermes Inc. Aristada ${ }^{\circledR}$ (aripiprazole lauroxil) extended-release injectable suspension, for intramuscular use. Waltham, MA: Alkermes Inc.; January 2018.

21. Spina E, Hiemke C, de Leon J. Assessing drug-drug interactions through therapeutic drug monitoring when administering oral second-generation antipsychotics. Expert Opin Drug Metab Toxicol. 2016; 12(4): 407-422.

22. Otsuka Pharmaceutical Co. Ltd. Abilify Maintena ${ }^{\circledR}$ (aripiprazole) for extended-release injectable suspension, for intramuscular use. Tokyo, Japan: Otsuka Pharmaceutical Co. Ltd; March 2018.

23. Janssen Pharmaceuticals Inc. Invega Trinza ${ }^{\circledR}$ (paliperidone palmitate) extended-release injectable suspension, for intramuscular use. Titusville, NJ: Janssen Pharmaceuticals Inc.; March 2018.

24. Janssen Pharmaceuticals Inc. Invega Sustenna ${ }^{\circledR}$ (paliperidone palmitate) extended-release injectable suspension, for intramuscular use. Titusville, NJ: Janssen Pharmaceuticals Inc.; March 2018.

25. Lisbeth P, Vincent H, Kristof M, et al. Genotype and co-medication dependent CYP2D6 metabolic activity: effects on serum concentrations of aripiprazole, haloperidol, risperidone, paliperidone and zuclopenthixol. Eur J Clin Pharmacol. 2016; 72(2): 175-184. 
26. Ganoci L, Lovric M, Zivkovic M, et al. The role of Cyp2d6, Cyp3a4/ 5 , and Abcb1 polymorphisms in patients using long-acting injectable risperidone. Clin Ther 2016; 38(10s): e10-e11.

27. Meyer JM. Understanding depot antipsychotics: an illustrated guide to kinetics. CNS Spectr 2013; 18(suppl 1): 58-67; quiz 68.

28. Meyer JM. Converting oral to long-acting injectable antipsychotics: a guide for the perplexed. CNS Spectr 2017; 22(S1): 14-28.

29. Schoretsanitis G, Spina E, Hiemke C, de Leon JA. systematic review and combined analysis of therapeutic drug monitoring studies for long-acting risperidone. Expert Rev Clin Pharmacol. 2017; 10(9): 965-981.

30. Heres S, Kraemer S, Bergstrom RF, Detke HC Pharmacokinetics of olanzapine long-acting injection: the clinical perspective. Int Clin Psychopharmacol. 2014; 29(6):299-312.

31. Correll CU, Rubio JM, Inczedy-Farkas G, et al. Efficacy of 42 pharmacologic cotreatment strategies added to antipsychotic monotherapy in schizophrenia: systematic overview and quality appraisal of the meta-analytic evidence. JAMA Psychiatry. 2017; 74 (7): $675-684$.

32. Galling B, Roldan A, Hagi K, et al. Antipsychotic augmentation vs. monotherapy in schizophrenia: systematic review, metaanalysis and meta-regression analysis. World Psychiatry 2017; 16 (1): 77-89.

33. Correll CU, Rummel-Kluge C, Corves C, et al. Antipsychotic combinations vs monotherapy in schizophrenia: a meta-analysis of randomized controlled trials. Schizophr Bull 2009; 35(2): 443-457.

34. Fleischhacker WW, Uchida H Critical review of antipsychotic polypharmacy in the treatment of schizophrenia. Int J Neuropsychopharmacol. 2014; 17(7): 1083-1093.

35. Haddad PM, Brain C, Scott J Nonadherence with antipsychotic medication in schizophrenia: challenges and management strategies. Patient Relat Outcome Meas. 2014; 5: 43-62.

36. Turncliff R, Hard M, Du Y, et al. Relative bioavailability and safety of aripiprazole lauroxil, a novel once-monthly, long-acting injectable atypical antipsychotic, following deltoid and gluteal administration in adult subjects with schizophrenia. Schizophr Res 2014; 159(2-3): 404-410.

37. Curry SH, Whelpton R, De Schepper PJ, et al. Plasma-fluphenazine concentrations after injection of long-acting esters. Lancet 1978; 1 (8075): 1217-1218.

38. Eli Lilly and Co. Zyprexa Relprevv@ (olanzapine) for extended release injectable suspension. Indianapolis, IN: Eli Lilly and Co.; January 2018.

39. Ereshefsky L, Mascarenas CA. Comparison of the effects of different routes of antipsychotic administration on pharmacokinetics and pharmacodynamics. J Clin Psychiatry. 2003; 64: 18-23.

40. Spanarello S, La FT. The pharmacokinetics of long-acting antipsychotic medications. Curr Clin Pharmacol. 2014; 9(3): 310-317.

41. Wiles DH, McCreadie RG, Whitehead A. Pharmacokinetics of haloperidol and fluphenazine decanoates in chronic schizophrenia. Psychopharmacology 1990; 101(2): 274-281.

42. Citrome L Aripiprazole long-acting injectable formulations for schizophrenia: aripiprazole monohydrate and aripiprazole lauroxil. Expert Rev Clin Pharmacol. 2016; 9(2): 169-186.

43. Janssen Pharmaceuticals Inc. Haldol $($ Decanoate 50 (haloperidol), HALDOL® Decanoate 100 (haloperidol) for IM injection only. Titusville, NJ: Janssen Pharmaceuticals Inc.; December 2017.

44. Par Pharmaceuticals Inc. Fluphenazine Decanoate-fluphenazine decanoate injection, solution. Chestnut Ridge, NY: Par Pharmaceuticals Inc.; October 2017.

45. Janssen Pharmaceuticals I. Risperdal Consta® (risperidone) long-acting injection. Titusville, NJ: Janssen Pharmaceuticals, Inc.; March 2018.

46. Lundbeck Canada Inc. Fluanxol® Flupentixol Tablets (as flupentixol dihydrochloride) $0.5 \mathrm{mg}, 3 \mathrm{mg}$, and $5 \mathrm{mg}$; Fluanxolß Depot (flupentixol decanoate) intramuscular injection 2\% and 10\% flupentixol decanoate. St. Laurent, QC, Canada: Lundbeck Canada Inc.; August 2016. 